\title{
The Influence of Brand Equity Against Trust in Brand Users of Services Transportation Ojek Online Go-Jek
}

\author{
Penulis : Eko Hari Saksono, Stikom Profesi Indonesia \\ Email : moneehs@ymail.com \\ Penulis : Arry Rahayunianto, Universitas Sahid Jakarta \\ email : rahayuarry@gmail.com
}

\begin{abstract}
In its development today there are many companies ojek service provider online. Brand strength (Brand Equity) to benchmark a brand can survive in the middle of crowded product or not. Brand equity or brand equity is a set of brand assets and liabilities associated with a brand, name, symbol that is able to increase or decrease the value provided by a product or service both to the company and to the customer. But strengthening the brand is not easy, the company must have some assets that can complement the brand remains strong in the middle of market share. And there are many other factors that must be considered in maintaining consumer confidence in the product. The purpose of this research is to find out whether the strength of Brand (Brand Equity) affect the Trust in Brand consumers or users on the brand to use the service Transport Ojek Online Go-Jek. The theory which is the reference in the analysis is the Informationintegration Theory approach. Information-integration for communicators centers on the way we accumulate and organize information about all people, objects, situations, and ideas that shape attitudes or a tendency to act in a positive or negative way. Research method that researcher use is survey method. Survey method is used to get data from a certain place that is natural, in collecting data, done by distributing questionnaires, test, interview, structured and so on. The analysis used by the researchers is regression analysis. Regression is intended to find the form of relationship of two variables or more in the form of a function or equation whereas correlation analysis aims to find the degree of closeness relationship two or more variables. The result of this research is to know the influence of brand equity to the trust on the brand of transportation service user of Go-Jek among students of Jakarta Usahid can be concluded that the regression result shows $Y$ is trust in brand and $X$ is the influence of brand equity, which means if the influence of brand equity increases, the brand is also increasing.
\end{abstract}

Keywords : Brand Equity, Trust in Brand, Information-IntegrationTheory

\section{PENDAHULUAN}

Jasa sering dipandang sebagai suatu fenomena yang rumit. Kata jasa itu sendiri mempunya banyak arti, dari mulai pelayanan pribadi sampai jasa sebagai suatu produk. Salah satu jasa transportasi umum yang paling efektif dan efisien adalah ojek.
Brand equity atau ekuitas merek adalah seperangkat aset dan liabilitas merek yang terkait dengan suatu merek, nama, simbol yang mampu menambah atau mengurangi nilai yang diberikan oleh sebuah produk atau jasa baik pada perusahaan maupun pada pelanggan.Dengan ada banyaknya 
pesaing setiap perusahaan akan melakukan segala upaya dalam mempertahankan usahanya dengan banyak cara meningkatkan kualitas produk, memperbanyak distribusi, agar mampu memperkuat kekuatan brand nya (Brand Equity) demi mempertahankan kepercayaan konsumen pada brand sehingga konsumen menggunakan produk atau jasa yang ditawarkan. Namun memperkuat brand tidaklah mudah, perusahaan harus memiliki beberapa asset yang dapat melengkapi brand tersebut tetap kuat di tengah pangsa pasar. Dan masih banyak factor lainnya yang harus dipertimbangkandalam menjaga kepercayaan konsumen pada produk.

Teori Penggabungan Informasi adalah : "Salah satu model paling populer yang menawarkan untuk menjelaskan pembentukan informasi dan perubahan sikap.

\section{Identifikasi Masalah}

Apakah kekuatan Brand (Brand Equity) berpengaruh terhadap Trust in Brandkepercayaan konsumen atau pengguna pada merek untuk menggunakan jasa transportasi Ojek OnlineGo-Jek.Acuan dalam mengalisis adalah dengan pendekatan penggabungan informasi (informationintegration) bagi pelaku komunikasi berpusat pada cara kita mengakumulasi dan mengatur informasi tentang semua orang, objek, situasi, dan gagasan yang membentuk sikap atau kecenderungan untuk bertindak dengan cara yang positif atau negatif.

\section{KAJIAN PUSTAKA}

\section{Merek}

Merek (brand) adalah "Sebuah merek (brand) adalah satu set janji, asosiasi, citra, dan emosi yang diciptakan oleh perusahaan untuk membangun kesetiaan dengan para konsumennya.
Merek (brand) itu dari dalam ke luar. Perusahaan anda mengendalikan janji, posisi, dan atribut dari merek (brand) anda. (John Foley dan Julie Kendrik : 2006)

"Nama, istilah, tanda, symbol atau desain, atau kombinasi diantaranya, yang dimaksudkan untuk mengidentifikasi barang dan jasa dari satu penjual atau sekelompok penjual dan membedakannya dari barang dan jasa para pesaingnya. ( Fandi Tjiptono : 2015)

Merek adalah inti dari identitas perusahaan yang terdapat kombinasi dari nama, istilah, tanda, symbol atau desain yang dapat membedakannya dari competitor.Merek adalah untuk mengidentifikasi produk sebagai hak milik atau kepunyaan organisasi tertentu dan untuk memfasilitasi diferensiasi suatu produk dari produk - produk pesaingnya.

Merek memiliki beberapa elemen sebagai berikut (Rangkuti : 2002) :

1. Brand name (nama merek), yaitu bagian yang dapat diucapkan.

2. Brand mark (tanda merek) merupakan sebagian dari merek yang dapat dikenali namun tidak dapat diucapkan, seperti lambang, desain huruf atau warna khusus.

3. Trade mark (tanda merek dagang) merupakan merek atau sebagian tanda merek yang dilindungi hukum karena kemampuannya untuk menghasilkan sesuatu yang istimewa. Tanda dagang ini melindungi penjual dengan hak istimewanya untuk menggunakan nama merek (tanda merek).

4. Copyright (hak cipta) yang merupakan hak istimewa yang dilindungi undang - undang untuk memproduksi, menerbitkan, dan menjual karya (Rama Kertamukti: 2015). 


\section{Band Equity}

Ekuitas merek (brand equity) adalah "nilai tambah yang diberikan pada produk dan jasa. Ekuitas merek dapat tercermin dalam cara konsumen berpikir, merasa, dan bertindak dalam hubungannya dengan merek, dan juga harga, pangsa pasar, dan profabilitas yang diberikan merek bagi perusahaan.(Philip Kotler dan Kevin Lane Keller : 2009)“"ekuitas merek adalah nilai tambah yang diberikan merek pada produk. Sepanjang nilai tambah ada, maka merek memiliki ekuitas".( Rama Kertamukti : 2015)

Brand equity adalah nilai tambah yang ada pada merek sehingga mampu mempengaruhi pola piker konsumen untuk memiliki keterlibatan dalam produk.Brand equity memberikan nilai bagi perusahaan dalam bentuk :

1) Brand equity yang kuat dapat mempertinggi keberhaasilan program dalam memikat konsumen baru atau merangkul kembali konsumen lama. Promosi yang dilakukan akan lebih efektif jika merek dikenal. Brand equity yang kuat dapat menghilangkan keraguan konsumen terhadap kualitas merek.

2) Empat dimensi brand equity: brand awareness, perceived quality, asosiasi - asosiasi tidak begitu penting dalam proses pemilihan merek, ketiganya tetap dapat mengurangi keinginan atau rangsangan konsumen untuk mencoba merek - merek lain.

3) Brand loyalty yang telah diperkuat merupakan hal penting dalam merenspon inovasi yang dilakukan para pesaing. Brand loyalty adalah salah satu barnd equity yang dipengaruhi oleh kategori brand equity lainnya. Kategori - kategori brand equity lainnya juga berhubungan satu sama lain. Perceived qulity dapat dipengaruhi oleh brand awareness. Nama merek dapat memberikan kesan bahwa produk dibuat dengan baik. (perceived quality), diyakinkan oleh asosiasi dan loyalitas (seorang konsumen yang loyal tidak akan menyukai produk yang lualitasnya rendah).

4) Brand association juga sangat penting sebagai dasar strategi positioning maupun strategi perluasa produk. Suatu analsisi terhadap portofolio merek sangat diperlukan untuk mengetahui efektifitas dari perluasan merek yang telah dilakukan.

5) Salah satu cara memperkuat brand equity adalah dengan melakuakan promosi besar - besaran yang membutuhkan biaya besar. Brand equity yang kuat memungkinkan perusahaan memperoleh margin yang lebih tinggi dengan menerapkan premium price, dan mengurangi ketergantungan pada promosi sehingga dapat diperoleh laba yang lebih tinggi.

6) Brand equity yang kuat dapat digunakan sebagai dasar untuk pertumbuhan dan perluasan merek kepada produk lainnya atau menciptakan bidang bisnis baru yang terkait yang biayanya akan jauh lebih amahal untuk dimasuki tanpa merek yang dimiliki brand equity tersebut.(Darmadi, Sugiarto, dan Tony Sitinjak : 2004)

\section{Indikator Brand Equity}

Brand equity dapat dikelompokan ke dalam lima kategori, yaitu :

1) Brand Awareness (kesadaran merek), menunjukan kesanggupan seorang calon pembeli untuk mengenali atau mengingat kembali bahwa suatu merek merupakan bagian dari kategori produk tertentu.

2) Brand Association (asosiasi merek) mencerminkan pencitraan suatu merek terhadap suatu kesan tertentu 
dalam kaitannya dengan kebiasaan, gaya hidup, manfaat, atribut produk, geografis, harga, pesaing, selebritis, dan lain - lain.

3) Perceived Quality (persepsi kualitas) mencerminkan persepsi pelanggan keseluruhan kualitas/keunggulan suatu produk atau jasa layanan berkenaan dengan maksud yang diharapkan.

4) Brand Loyalty (loyalitas merek) mencerminkan tingkat keterikatan konsumen dengan suatu merek produk.

5) Other Proprietarry Brand Assets atauasset - asset merek lainnya(Darmadi, Sugiarto, dan Tony Sitinjak : 2004)

\section{Kepercayaan Merek (Brand Trust)}

Lau dan Lee (1999)

mendefinisikan trust terhadap sebuah merek (trust in a brand) sebagai kesediaan konsumen untuk mempercayai atau mengandalkan merek dalam situasi resiko dikarenakan adanya ekspetasi bahwa merek bersangkutan akan memberikan hasil positif(Darmadi, Sugiarto, dan Tony Sitinjak : 2004)

\section{Indikator Trust In A Brand / Brand Trust}

Lau dan Lee (1999) menguji model konseptual yang terdiri atas sejumlah factor berupa karakteristik merek, karakteristik perusahaan, dan karakteritik relasi antara konsumen dan merek.

Sedangkan factor - factor yang berperan penting dalam membentuk trust terhadap merek meliputi brand predictability, brand liking, brand competence, brand reputation, dan trust in the company.

Brand predictability mengacu pada kemampuan pelanggan untuk mengantisipasi (dengan tingkat keyakinan yang reasonable) kinerja merek pada berbagai situasi pemakaian.

Predictability bisa terbentuk sebagai hasil interaksi ulangan dan konsistensi tingkat kualitas produk / jasa.

Brand liking berkaitan dengan apakah merek tertentu disukai atau tidak oleh pelanggan.

Brand competence mengacu pada kemampuan merek untuk memecahkan masalah pelanggan dan memenuhi kebutuhan atau keinginan pelanggan. Kompetensi merek bisa dinilai pelanggan melalui pengalaman pemakaian produk / jasa langsung maupun lewat komunikasi gethok tular.

Brand reputation mengacu pada pendapat orang lain bahwa merek bersangkutan bagus dan andal. Reputasi merek bisa terbentuk melalui perikalanan, public relation, kualitas produk, dan kinerja produk / jasa. Trust in the company adalah tingkat kepercayaan pelanggan terhadap perusahaan yang memiliki merek bersangkutan.( Fandi Tjiptono : 2014)

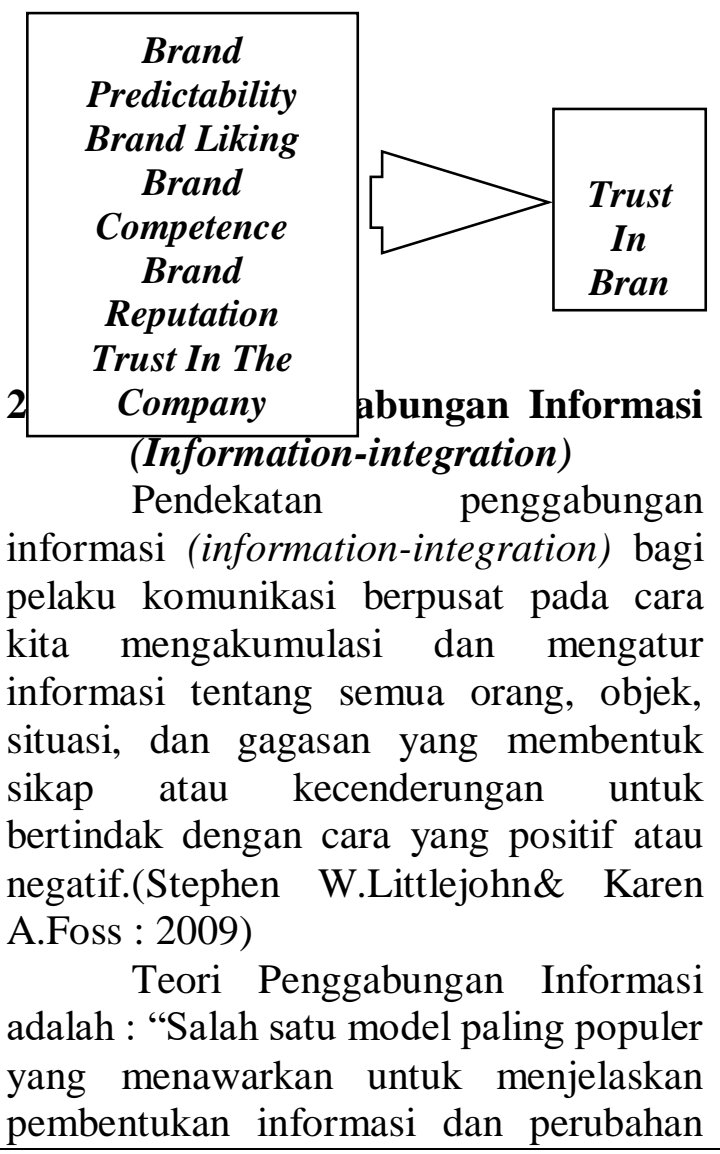
Users Of Services Transportation Ojek Online Go-Jek 
sikap.(Stephen W.Littlejohn\& Karen A.Foss : 2009)

Konsep kognisi yang
digambarkan sebagai sebuah kekuatan sistem interaksi. Informasi adalah salah satu dari kekuatan tersebut dan berpotensi mempengaruhi sebuah sistem kepercayaan atau sikap individu. Sebuah sikap dianggap sebagai sebuah akumulasi dari informasi tentang sebuah objek, seseorang, situasi, atau pengalaman. Dua variabel yang memiliki peranan penting dalam memengaruhi perubahan sikap, yaitu Valence atau arahan dan Bobot yang diberikan terhadap informasi. Pertama, Valence atau arahan mengacu pada apakah informasi mendukung keyakinan komunikator atau menyangkal komunikan. Ketika informasi mendukung keyakinan komunikator, maka informasi tersebut mempunyai valence "positif". Ketika tidak mendukung, maka valence "negatif".

Hubungan variabel valence dalam memengaruhi perubahan sikap, dapat dikatakan bahwa merek yang memiliki kekuatandapat melakukan komunikasi dengan mempengaruhi konsumen atau penggunanyauntuk membangun rasa kepercayaan konsumen atau pengguna pada merek, maka akan menciptakan valence yang positif. Dan apabila merek tidak memiliki kekuatan bahwa tidak dapat melakukan komunikasi dngan mempengaruhi untuk terbentuknya rasa kepercayaan konsumen atau pengguna terhadap merek, maka akan menciptakan valence yang "negatif".

$$
\text { Variabel kedua yang }
$$

memengaruhi dampak dari informasi adalah bobot yang komunikator berikan terhadap informasi. Bobot adalah sebuah kegunaan dari kredibilitas. Maksudnya adalah, ketika komunikator merasa yakin bahwa informasi tersebut adalah benar, maka komunikator akan memberikan bobot yang lebih tinggi pada informasi tersebut; jika tidak, maka komunikator akan memberikan bobot yang lebih rendah.

Semakin besar bobot yang diberikan, semakin besar pula dampak dari informasi tersebut. Jika merek yang bertindak sebagai komunikator, dalam melakukan komunikasi dengan konsumen, atau penggunanya yang bertindak sebagai komunikan,jika merek memberikan bobot besar dalam menyampaikan informasinya mengenai kualitas produkidentitas perusahaan dan bahkan mampu mempengaruhi apa saja, jika konsumen atau pengguna memiliki rasa aman dan nyaman terhadap merek dengan kekuatan merek tersebut, maka konsumen atau pengguna akan terpengaruh untuk percaya pada brand yang digunakan, yang merupakan tindakan positif.

\section{Hipotesis}

Adanya pengaruh brand equity terhadap kepercayaan pada merek pengguna jasa transportasi Go-Jek. di kalangan mahasiswa Usahid Jakarta

\section{METODE PENELITIAN}

Metode penelitian yang peniliti gunakan adalah metode survey.

Kriteria yang dijadikan pertimbangan :

1. Mahasisiwa Universitas Sahid Jakarta

2. Menggunakan Ojek Online Go-Jek $\geq 2$ kali seminggu.

\section{Operasional Variabel}

Variabel X : Pengaruh Brand Equity

Indikator 1. BrandAwareness

2. Brand Association Perceived

3. Quality (kualitas merek)

4. Brand Loyalty (keterikatan merek)

5. Other ProprietarryBrand Assets (asset tambahan) 
Variable Y : Trust in Brandpengguna jasa transportasi Ojek Online Go-Jek

Indikator : 1. Brand Predictability (kinerja merek)

2. Brand Liking (merek disukai)

3. Brand Competence (kemampuan merek)

4. Brand Reputation (reputasi merek)

5. Trust In The Company (kepercayaan pada perusahaan)

\section{Teknik Pengumpulan Data}

1. Angket / Kuesioner

2. Studi Pustaka

\section{Sampel}

Sampel diambil secara proposional stratified sampling dari lima fakultas, diperoleh sampel sebanyak 100 orang mahasiswa.

\section{Teknik Analisis Data}

Teknik yang digunakan peneliti dalam menganalisa data adalah Regresi Linier Sederhana.

$$
\mathbf{Y}=\mathbf{a}+\mathbf{b X}
$$

\section{Uji Hipotesis}

Menggunakan rumus Pearson Product Moment Correlation

$$
r=\frac{n \sum x y-\left(\sum x\right) \sum(y)}{\left.\sqrt{\left\{n \sum x^{2}\right.}-\left(\sum x\right)^{2}\right\}\left\{n \sum y^{2}-\left(\sum y\right)^{2}\right.}
$$

\section{HASIL DAN PEMBAHASAN}

Identitas responden merupakan identitas mahasiswa Usahid Jakarta dengan persentase $(45,70 \%)$ adalah berjenis kelamin pria. Sedangkan, wanita dengan persentase $(54,20 \%)$. Dengan demikian dapat disimpulkan bahwa mayoritas responden berjenis kelamin wanita.

\section{Variabel X : Pengaruh Brand Equity}

\section{Brand awareness (kesadaran merek)}

Seluruhresponden menjawab "setuju", yaitu sebanyak 100atau(100\%)responden menjawab mengetahui merek Go-Jek, responden menjawab "setuju", yaitu sebanyak 100atau (100\%) responden nama perusahaan mudah diingat, seluruhresponden menjawab "setuju", yaitu sebanyak 100respondendengan persentase $(100 \%)$. Dengan banyaknya responden yang menjawab setuju maka dapat disimpulkan bahwa reponden mampu membedakan Go-Jek diantara merek Ojek On-Line lainnya

Hasil akhir untuk indicator brand awareness (kesadaran merek) dapat dilihat melalui grafik, sebagai berikut :

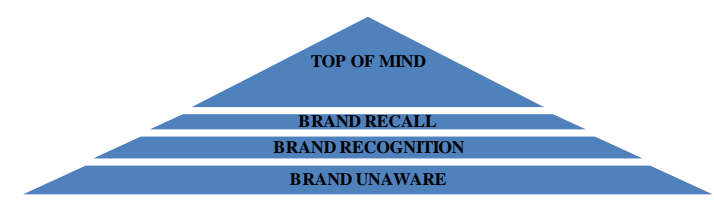

Keterangan :

1. Top of mind (puncak pikiran)

2. Brand recall (dapat mengingat kembali)

3. Brand recognition (brand dikenali)

4. Brand unware (brand tidak dapat dikenali)

Berdasarkan grafik tersebut Go-Jek berada di tingkat top of mind atau puncak pikiran karena kemampuan responden yang tidak hanya mengenali merek, tetapi juga mampu mengingat kembali dan membedakan Go-Jek dengan merek lainnya, hal tersebut menjadikan brand awarnessGo-Jeksebagai salah satu faktor pendorong kekuatan merek Go-Jek itu sendiri.

\section{Brand association}


Sebagian besar responden menjawab "kurang setuju", yaitu sebanyak 65dengan persentase $(65 \%)$. Banyaknya responden yang menjawab kurang setuju pada harga yang diterapkan Go-Jekdibanding dengan merek lainnya, tariff Go-Jek terbilang lebih mahal, sebagian besar responden menjawab "setuju", yaitu dengan persentase (94\%). Banyaknyaresponden yang menjawab setuju bahwa Go-Jekmemiliki sarana yang memadai, karena sarana pendukung yang dimiliki berupa maps, radio, sambungan langsung ke operator official Go-Jek. Dengan demikian pengguna jasa Go-Jekpun merasa nyaman dalam menggunakan Go-Jekbaik dalam waktu perjalanan yang singkat maupun yang membutuhkan waktu yang panjang.

\section{Perceived quality (kualitas merek)}

Responden menjawab "setuju", yaitu sebanyak 74respondendengan persentase $(74 \%)$. Banyaknya responden yang menjawab setuju bahwa Go-Jek memiliki driver dengan soft skill yang aman dan nyaman saat berkendara, karena dalam menjalankan usaha jasa di bidang transportasi, Go-Jek menerapkan syarat dalam perekrutan driver sesuai dengan standar, sebagian besar responden menjawab "setuju", yaitu sebanyak 66 atau (66 \%) responden bahwa identitas driver kredibel atau dipercaya, karena SOP Go-Jek yang menerapkan identitas driver tertera pada aplikasidan sesuai dengan aslinya, dengan demikian penumpang dapat mengantisipasi hal - hal yang tidak diinginkan.

\section{Loyality Brand (keterikatan konsumen dengan merek)}

Sebagian besar responden menjawab "setuju", sebanyak 51 atau (51 $\%)$ responden bahwa taxi Go-Jek menjadi pilihan utamanya, karena tidak lepas dari factor lainnya seperti brandawareness, perceived quality, brand association dan another asset yang dapat mempengaruhi keputusan pengguna menempatkan Go-Jek menjadi pilihan utamanya, sebagian besar responden menjawab "setuju" sebanyak 88 atau $(88 \%)$ responden bahwa taxi GoJek menjadi rekomendasi, karena tidak lepas dari kepuasan pengguna itu sendiri atau pengalaman dari pengguna lainnya saat terlibat dengan produk atau menggunakan langsung jasa transportasi Go-Jek.

\section{Another asset}

Sebagian besar responden menjawab "setuju", yaitu sebanyak 71 atau (71\%).responden bahwa aplikasi pemesanan via online "Go-Jek" diketahui karena Go-Jek merupakan usaha jasa transportasi ojek yang pertama menggunakan aplikasi via online di Indonesia, sebagian besar responden menjawab "Setuju", yaitu sebanyak 79 atau $(79 \%)$ responden menjawab setuju bahwa aplikasi Go-Jek memudahkan dalam pemesanan, karena pengguna tidak perlu repot lagi pergi ke jalan umum atau mengeluarkan pulsa telepon hanya untuk memesan ojek online, sebagian besar responden menjawab "setuju", yaitu sebanyak 65 atau $(65 \%)$ responden menjawab setuju bahwa aplikasi Go-Jek mudah digunakan tidak memakan waktu lama, tidak menggunakan prosedur yang sulit, dan petunjuk penggunannya mudah dipahami.

\section{Variabel Y : Kepercayaan Pada Merek}

\section{Brand Predictability (kinerja merek)}

Sebagian besar responden menjawab "setuju", yaitu sebanyak 51 atau $(51 \%)$.responden menjawab bahwa Go-Jek dapat diandalkan dalam ketepatan waktu, karena memiliki driver yang berpengalaman, dengan demikian pengguna nyaman menggunakan, sebagian besar responden menjawab 
"setuju", yaitu sebanyak 62 atau (62\%) yang menjawab bahwa Soft skill driver berpengalaman dalam menyelesaikan masalah saat berkendara, karena Go-Jek melatih drivernya tidak hanya terampil saat berkendara tetapi juga terampil untuk menggunakan teknologi yang memang dipersiapkan untuk membantunya saat berkendara, yaitu maps dan alat penghubung langsung ke bagian operasional officer.

\section{Brand Liking}

Sebagian besar menjawab "tidak setuju" bahwa menggunakan Go-Jek 2x dalam seminggu, yaitu sebanyak 82 atau (82 \%)respondenmenjawab karena kebutuhan responden akan penggunaan jasa transportasi Go-Jek tinggi, dan hampir setiap hari, sebagian besar responden menjawab "setuju", yaitu sebanyak 67 atau (67\%)responden menjawab bahwa Go-Jek lebih disukai dibanding merek lainnya karena pengguna merasa aman dan nyaman saat menggunakan Go-Jek.

\section{Brand Competence}

Sebagian besar responden menjawab "Setuju", yaitu sebanyak 60 atau (60 \%).responden yang menjawab bahwa Go-Jek adalah yang terbaik, karena Go-Jek menerapkan standar kualitas yang tinggi dalam jasanya baik melalui 14 macam sarana aplikasinya sebagai hiburan, sarana pelengkap, maupun pelayanan dari drivernya, sebagian besar responden menjawab "setuju", yaitu sebanyak 88 atau (88\%) responden menjawab bahwa Go-Jek aman, nyaman dan efisien, karena menerapkan standar kualitas yang tinggi demi mencapai misinya yaitu kepuasan pelanggan atau pengguna.

\section{Brand Reputation}

Sebagian besar responden menjawab "Setuju", yaitu sebanyak 77 atau $(77 \%)$ responden menjawab bahwa tidak pernah mendapat informasi identitas driver tidak dapat dipercaya karena untuk mencegah terjadi hal tersebut di setiap armada Go-Jek selalu menampilkan identitas driver, sebagian besar responden menjawab "setuju", yaitu sebanyak 81 atau (81\%) responden yang menjawab bahwa tidak pernah mendapat informasi driver tidak berpengalaman, karena untuk mencegah terjadinya hal tersebut Go-Jek mengantisipasi dengan memberikan pelatihan pada setiap driver, sebagian besar responden menjawab "setuju", yaitu sebanyak 91 atau (91,40\%) responden mendapat InformasiGo-Jek aman dan nyaman berkendara, karena sebagai acuan untuk mempercayai sebuah merek, tidak hanya factor dari pengalaman diri sendiri, pengalaman dari orang lain pun dapat mempengaruhi dalam menimbulkan rasa kepercayaan pada merek.

\section{Trust In The Company}

Sebagian besar responden menjawab "Setuju", sebanyak 91 atau (91 \%) responden bahwa saya mempercayaiGo-Jekkarena menerapkan standar kemanan dan kenyamanan di setiap produk atau jasa transportasi miliknya, sebagian besar responden menjawab "setuju", yaitu sebanyak 91 atau $(91 \%)$ responden menjawab bahwa produk jasa Go-Jek aman digunakan, karena responden mengalami sendiri bagaimanaGo-Jek memprioritaskan kepuasan penggunanya melalui pelayanan drivernya, sebagian besar responden menjawab "setuju", yaitu sebanyak 94 atau $(94 \%)$ responden menjawab bahwa Go-Jek dapat diandalkan dalam menghasilkan produk jasa transportasi yang aman dan nyaman, karena dengan penilaian pengguna yang positif akan kemanan Go-Jek, hal tersebut dapat mempengaruhi pengguna 
untuk memberikan nilai positif lagi apabilaGo-Jek menghasilkan produk atau jasa transportasi lainnya.

Regresi Linier Sederhana sebagai berikut:

$\mathrm{Y}=\mathrm{a}+\mathrm{bX}$

Dimana:

$\mathrm{Y}=$ variabel tidak bebas (subjek dalam variabel tak bebas /dependen yang diprediksi)

$\mathrm{X}=$ variabel bebas (subjek pada variabel independen yang mempunyai nilai tertentu)

$\mathrm{a}=$ nilai intercept (konstan) atau harga $\mathrm{Y}$ bila $\mathrm{X}=0$

$\mathrm{b}=$ koefisien regresi, yaitu angka peningkatan atau penurunan varaibel dependen yang didasarkan pada variabel independen. Bila b (+) maka naik, bila $b$

(-) maka terjadi penurunan.

Nilai a

$\alpha=\frac{\sum Y\left(\sum X^{2}\right)-\sum X \sum X Y}{n \sum X^{2}-\left(\sum X\right)^{2}}$

$\alpha=8,56$

Nilai b

$b=\frac{n \sum X Y-\sum X \sum Y}{n \sum X^{2}-\left(\sum X\right)^{2}}$

$b=0,63$

Maka, hasil regresi yang diperoleh :

$\mathbf{Y}=\mathbf{8 , 5 6}+\mathbf{0 , 6 3} \mathrm{X}$

dimana :

$\mathrm{Y}=$ Kepercayaan pada merek

$\mathrm{X}=$ Pengaruh Brand Equity

\section{Interpretasi dari koefisien regresi :}

Nilai a = artinya jika pengaruh brand equity nilainya adalah 0 maka kepercayaan pada merek pengguna jasa transportasi Go-Jek yaitu 6,58.

Nilai $b=$ artinya jika terjadi peningkatan kepercayaan pada merek pengguna jasa tranportasi Go-Jek, maka akan terjadi peningkatan pengaruh Brand Equity sebesar 0,70 .

\section{Uji Kesetaraan antara Variabel $X$ terhadap Variabel Y}

Selanjutnya untuk pengujian seberapa jauh keeratan antara Variabel X (Pengaruh Brand Equity) terhadap Variabel Y (Kepercayaan Pada merek Pengguna Jasa Transportasi GoJekdikalangan mahasiswa Usahid Jakartadigunakan rumus koefisien korelasi Pearson's correlation (product moment).

Rumus Pearson's digunakan untuk menguji hubungan antara dua variabel, didapat hasil

$\mathrm{r}=\frac{7690}{9435} \mathrm{r}=0,81$

Koefisien korelasi untuk perhitungan statistik tersebut sebesar 0,81 yang terletak antara $0,71-0,90$ yang artinya hubungan variabel $X$ dan variabel Y kuat antara "Pengaruh Brand Equity Terhadap Trust in Brand Pengguna Jasa Transportasi GoJekdikalangan mahasiswa Usahid Jakarta".

\section{Penerapan Teori Pendekatan Penggabungan Informasi (Information - Integration).}

Information - Integration adalah teori yang membahas tentang informasi yang berguna baik itu untuk menentukan pembentukan informasi dalam pesan non verbal maupun menimbulkan adanya feedback, yaitu perubahan sikap. Sehingga komunikator akan lebih mudah dalam mengevaluasi pembentukan informasi dalam bentuk asset - asset pendukung agar menghasilkan pesan yang efektif sehingga dapat diterima komunikannya.

Model ini bermula dengan konsep kognisi yang digambarkan sebagai sebuah kekuatan sistem interaksi. Informasi adalah salah satu dari kekuatan tersebut dan berpotensi memengaruhi sebuah sistem kepercayaan atau sikap individu. Sebuah sikap dianggap sebagai 
sebuah akumulasi dari informasi tentang sebuah objek, seseorang, situasi, atau pengalaman.

Dua variabel yang memiliki peranan penting dalam memengaruhi perubahan sikap, yaitu Valence atau arahan dan Bobot yang diberikan terhadap informasi. Pertama, Valence atau arahan mengacu pada apakah informasi mendukung keyakinan komunikator atau menyangkal komunikan. Ketika informasi mendukung keyakinan komunikator, maka informasi tersebut mempunyai valence "positif". Ketika tidak mendukung, maka valence "negatif".

Jika menghubungkan variabel valence dalam memengaruhi perubahan sikap, pada penelitian ini, dapat dikatakan bahwa merek yang memiliki kekuatandapat melakukan komunikasi dengan mempengaruhi konsumen atau penggunanyauntuk membangun rasa kepercayaan konsumen atau pengguna pada merek, maka akan menciptakan valence yang positif.Dan apabila merek tidak memiliki kekuatan bahwa tidak dapat melakukan komunikasi dengan mempengaruhi untuk terbentuknya rasa kepercayaan konsumen atau pengguna terhadap merek, maka akan menciptakan valence yang "negatif".

Informasi yang dibentuk menjadi sebuah pesan melalui asset asset pendukung baik lambang, symbol maupun perilaku komunikator (merek) menciptakan valence yang positif karena hasil penelitian ini menunjukan adanya feedback dalam perubahan sikap dari tidak percaya menjadi percaya. Adanya nilai positif yang responden berikan kepada asset -asset pendukung merek tersebut memberikan bobot yang tinggi terhadap informasi yang dibentuk sehingga kekuatan dari sebuah merek pun meningkat.

Kognisi didapatkanmelaluiasset asset pendukung yang digunakan memiliki pengaruh terhadap kepercayaan pada merek. Responden memberikan nilai positif pada asset - asset dari merek, sehingga responden yakin dan percaya pada merek jasa transportasiGoJek.

\section{KESIMPULAN}

Tujuan penelitian yaitu untuk mengetahui pengaruh brand equity terhadap kepercayaan pada merek pengguna jasa transportasi Go-Jek diikalangan mahasiswa Usahid Jakarta dapat disimpulkan bahwa hasil regresi menunjukan Y adalah kepercayaan pada merek dan $\mathrm{X}$ adalah pengaruh brand equity, yang artinya jika pengaruh brand equity meningkat, maka kepercayaan pada merek pun juga semakin meningkat.

\section{REFERENSI}

Manajemen Pemasaran Jasa

Merencanakan, Mengelola, dan Membidik Pasar Jasa, Yogyakarta CAPS 2015

Julie Kendrik, John Foley, Balanced Brand Strategi Memenangkan Pasar Dengan Menyeimbangkan Kekuatan Brand Dan Reputasi Perusahaan, Transmedia, Jakarta : 2006

Karen A.Foss,Stephen W.Littlejohn, Teori Komunikasi, Jakarta : Salemba Humanika, 2009

Kertamukti, Rama, Strategi Kreatif dalam Periklanan Konsep Pesan, Media, Branding, Anggaran, PT RAJA GRAFINDO, Jakarta, 2015

Kevin Lane Keller, Philip Kotler, Manajemen Pemasaran Edisi 13 Jilid 1 education, 2009

Nazir, Moh., Metode Penelitian, Ghalia Indonesia, Bogor, 2005 
Sugiyono, Metode Penelitian Kuantitatif kualitatif dan $R \& D$, Alpha Beta, Bandung, 2010

Tjiptono, Fandi,Pemasaran jasa prinsip, penerapan, dan penelitian, Andi Yogyakarta : 2014

Tjiptono, Fandi, Strategi Pemasaran Edisi 4, ANDI Yogyakarta : 2015

Tony Sitinjak,Darmadi, Sugiarto, Strategi Menaklukan Pasar Melalui Riset Ekuitas dan Perilaku Merek, Jakarta : 2004 